\title{
RECLAIMING THE ENVIRONMENT-ORGANIZATION FIT: \\ MATCHING TURNAROUND STRATEGIES \\ TO ENVIRONMENTAL EXIGENCIES
}

\author{
Ananda Mukherji \\ Texas A\&M International University \\ Laredo, TX \\ Ashay Desai \\ University of Wisconsin - Oshkosh \\ Oshkosh, WI \\ John Francis \\ Mississippi College \\ Jackson, MS
}

\begin{abstract}
This paper discusses the relationship a firm has with its total environment in the context of decline. We dimensionalize the total environment to exist at the (I) organization, (2) industry, and (3) macro levels. These levels impact the firm directly, and indirectly through interactions of the different levels. Each level of the environment or combination of levels has forces acting in similar or in different directions which results in uniquely different and complex conditions for firms facing decline. We suggest that the firm has to assess its environment carefully, establish the nature of environmental impact, and develop turnaround strategies to match the pressures of its multilayered environment in order to become competitive.
\end{abstract}

\section{Introduction}

One of the most pressing challenges firms face during their lifetime is understanding causes of decline, and managing the turnaround process. Many researchers have been studying the consequences of decline, and the process of turnaround (Cameron, Whetten \& Kim, 1987; Hofer, 1980; Robbins \& Pearce, 1992). Although research originally centered on the operational aspects of turnaround, namely retrenchment of expenses and reduction of assets, the scope has expanded to other issues, such as management of human resources, capital restructuring, market choice, and selective product divestiture (Bibeault, 1982; Pearce \& Robbins, 1993; Starbuck, Greve, \& Hedburg, 1978). Currently there is a developing stream of literature which studies the impact of environment, environmental changes on firms (Castrogiovanni, 1991; Hannan \& Freeman, 1977; Starbuck, 1976), and responses of firms to such changes (Covin \& Slevin, 1990; Hambrick \& Schectar, 
1983). Research in the environment-organization relationship exhorts the importance of the alignment of a firm's strategies and resources with environmental requirements to be one of the critical steps in achieving desirable performance (Child, 1971; Dill, 1958; Venkatraman \& Camillus, 1984).

This paper considers the firm-environment fit as an important ingredient in the quest for reclaiming lost competitive advantage, and develops some suggestions for researchers and managers. In order to ground behavior of firms to changes in the environment, we believe the very definition of the environment has to be made much more explicit. There have been many varying definitions of what constitutes the environment (Aldrich, 1979; Castrogiovanni, 1991; Dess \& Beard, 1984). While researchers have been identifying components of the environment along several dimensions, most of them have essentially treated it as a unilevel construct. The emphasis regarding firm environment in this paper is not so much with its varying definitions, but with how different aspects of the environment are interrelated to each other, and how these interrelated parts differentially impact organizations. We discuss the topic of developing appropriate turnaround strategies by addressing three substantial issues.

The first issue is that of defining a more structured, tier-oriented denotation of the environment. For example, one level of the environment should include aspects beyond the industry, another level may be at an intra-industry level, and so on. The stand we take in this paper is that different levels of the environment could impact firms differently, especially if they move in different directions. The second concern is the importance of assessing causality of decline, i.e., to understand how and why firms are being impacted. The third is to look at a range of strategic and tactical options available to the firm, and to understand the relationship between a particular set of environmental conditions and the organization's options. The underlying theme of the paper is that a clear description of the different levels of the environment, and the effect of each level on declining firms would help identify appropriate responses to achieve turnaround.

Most strategy literature and research treats the environment as a single construct that can be categorized as being adverse and hostile on the one hand, as opposed to be being munificent and liberal on the other. The contribution of this paper is that such an omnibus classification is misleading, if not inappropriate. As this paper will attempt to show, different levels of the environment may pull in different directions (one level being hostile and the another munificent), and firms may have to exhibit different and unique responses. These responses would depend upon understanding and mapping the total environment and its many levels.

\section{Turnaround: Situations and Strategies}

Organizations eventually suffer a decline in performance sometime during their lifetime; some of them manage to recover while others do not. Hambrick and D'Aveni (1988) highlight the growing importance of turnaround processes 
by citing Business Week statistics which report the annual failure rate per 10,000 large firms growing from 100 during 1967 through 1982 to over 300 since 1985. This problem is further escalated, by the number of new business formations not offsetting the increase in business failures (Cameron, Sutton \& Whetten, 1988).

Cameron, Kim and Whetten (1987) define decline as a condition in which a substantial, absolute decrease in an organization's resource base occurs over a period of time. Krueger and Willard (1991) suggest that a firm is said to face a situation requiring turnaround when it has experienced an absolute decline in earnings in two consecutive years. This is a useful a priori condition as it controls for any cyclical or seasonal pattern of decline faced by the organization. This in turn, indicates that turnaround is a result of management actions taken in situations which are continually adverse. Many researchers suggest that turnaround involves an organizational metamorphosis consisting of alterations in the firm's ideology, strategy and structure (Barker \& Duhaime, 1994). Turnaround is said to have been achieved when the firm has been transformed from a position of decline to a position of strength and competitiveness (Stopford \& Baden-Fuller, 1990). Thus, attempted turnaround is not an event and is certainly not achieved overnight. We look at turnaround as a process which requires meticulous planning in order to achieve the fit between components of the organization and their corresponding sub-environments with which they share a reciprocal relationship.

Research in this area originally centered on operational aspects of turnaround, namely retrenchment of expenses and reduction of assets. Turnaround theorists thus prescribed cost cutting, tighter controls, and laying off personnel as the solution to a successful return to profitability (Starbuck, Greve \& Hedburg, 1978). Recently, the perspective has shifted towards strategic turnarounds that involves much more than efficiency increasing processes. Hofer (1980) provides a distinction between operational and strategic endeavors, which is either improving efficiency or changing the firm's basic strategy in order to achieve a fit with environmental conditions. In addition, he broadly divided research in the turnaround area into two streams: the content of the turnaround, and the process of turnaround (Hofer, 1980). Harrigan's (1980) seminal work on declining organizations has added theoretical robustness to this stream of literature. Concentrating on strategies for firms in declining industries and the variables that affect the choice of strategies, she suggests that several strategic options could be available to the firm depending on the environmental situation and the internal capabilities of the firm.

This paper suggests that a lot of the research related to firm decline, both conceptual and empirical, addresses a limited part of the overall issue. Based on Hofer's (1980) work, a number of researchers have undertaken empirical studies to better understand this relationship. On close examination, Hofer's (1980) paper does not specifically address the external environment and its impact on the organization. Rather, it is a method of assessing firm performance over various functions like its market position, technological strengths, and overall health. Based 
on this assessment of the internal environment, he prescribes certain ways to redeem the situation.

Hambrick and Schectar (1983), in studying the behavior of firms, have used cluster analysis to assess the possible relationship between Hofer's conceptual assessment, and actual firm behavior. Although their results were mixed, they were generally supportive of Hofer's overall contentions. On closer look, strategic moves were essentially tactical or operational in nature such as pricing, capacity utilization, and production. Hambrick and Schectar mention, "One of the weaknesses of the research design was a lack of data on the origin of the business's trouble, or how long the business had been in trouble" (1983: 240). Correctly identifying and assessing the source of the problem and subsequent firm action, one of the underlying issues of research in studying environment and declining firm behavior, has been largely ignored. Rather, debate has been in assessing the efficacy of a few strategic and numerous operational actions that firms undertake to overcome adverse performance.

We propose the need for a larger framework that helps identify and assess the source of the problem, and relate it to subsequent efforts made by the firm. We also suggest that the distinctions made by Pearce and Robbins (1993) in dichotomizing a limited set of organizational actions into strategic and operational responses to counter problems of decline and turnaround may be somewhat artificial, unless such categorizations can be thoroughly explained as we attempt to do in this paper. In doing so, we also enlarge the scope of what can be considered strategic under the rubric of organizational response.

\section{Conceptualizing The Environment}

While the debate on the environment, its varying components and definitions, and its impact on organizations has continued in the management literature for a long time, there has been some disagreement on what precisely constitutes the environment (Castrogiovanni, 1991; Dess \& Beard, 1984; Gerloff, Muir \& Bodensteiner, 1991; Sharfman \& Dean, 1991). Specifically, there are considerable differences among scholars over conceptualizing the environment, and defining the components of the environment, and its measures (Dess \& Beard, 1984; Sharfman \& Dean, 1991). The treatment of the environment as an objective reality as opposed to a perceptual phenomenon further complicates this debate. Substantial discussion exists on whether the 'objective' environment differs substantially from the 'perceived' environment, and if so, what are the implications of these differences (Bourgeois, 1985). Sharfman and Dean (1984) submit that research has been unable to build a comprehensive conceptualization of the environment or its measurement, and the precise impact the environment has on the firm. Nevertheless, Aldrich's (1979) typology of environmental dimensions, and Dess and Beard's (1984) measurements have become the basis for much of contemporary research that has been examining the relationship between the firm 
and its environment (Keats \& Hitt, 1988). In this paper, we take the stand that there are three levels of the environment, each impacting the firm in a different manner, and the subsequent section explicates these three levels.

\section{Three Levels of the Environment}

In order to clarify the various conceptualizations of the environment, Castrogiovanni (1991) suggested a multilevel model which explains different aspects of the environment. Rather than look at the environment as a single variable, he segmented it into different levels and suggested that each of the levels affects firms in different ways. We find Castrogiovanni's (1991) five level model somewhat complex and cumbersome, as three of the five levels are within the organization itself. Hence we propose that the total environment can be more effectively conceived as consisting of three distinct parts or levels. The first two levels are consistent with Castrogiovanni's (1991) model, but the third, the organization level, is created by collapsing three of Castrogiovanni's (1991) levels resources, sub-environment, and organizations - into one aggregate level.

Figure 1

\section{Forces at Three Levels Impacting Firms}

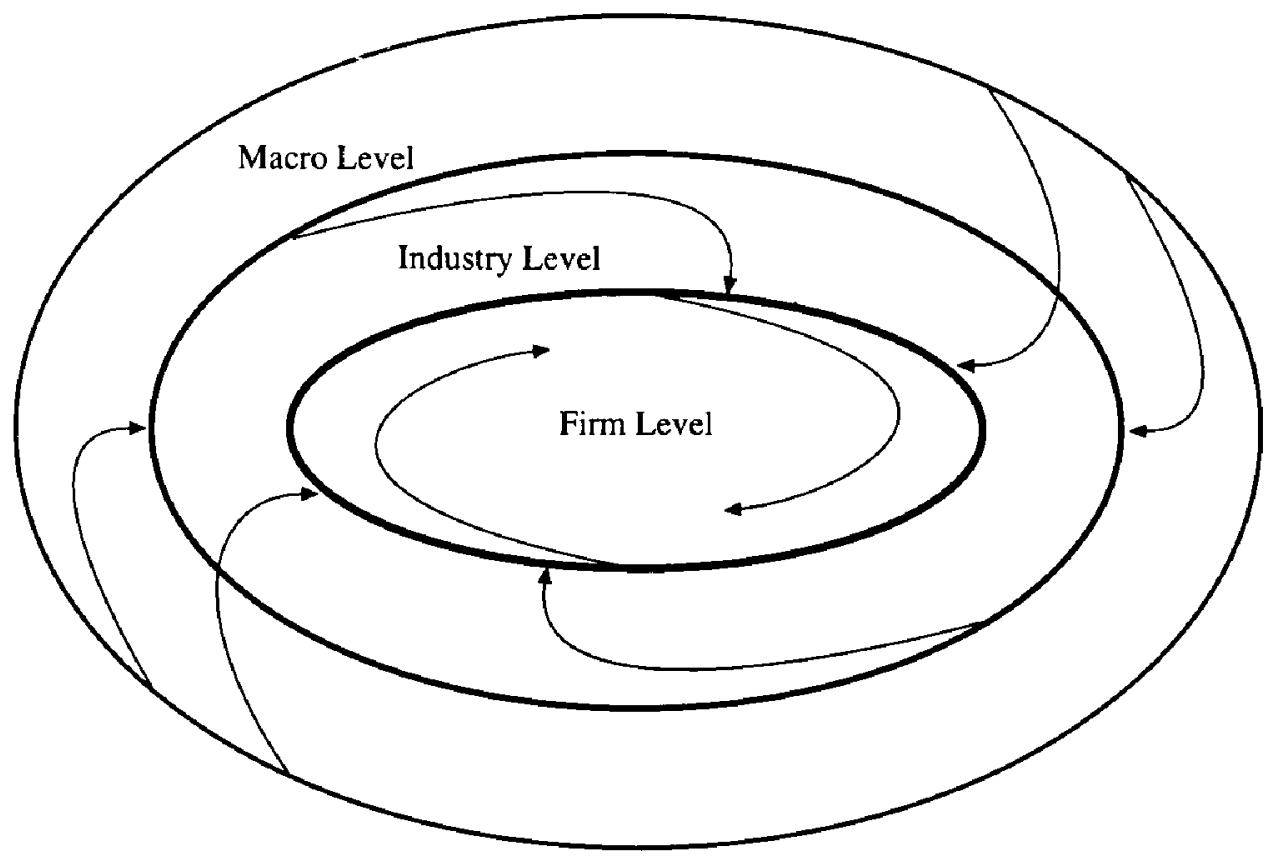

In summary, the three levels of the environment we present and discuss next are: (1) organization; (2) industry; and (3) macro levels, respectively. 


\section{Organization Level}

The first level, the internal environment of the firm, consists of its overall set of resources, its functional sub-environments, and its internal competencies (Selznick, 1957; Barney, 1991). The firm can determine its own performance by way of its capabilities and unique competencies independent, to the extent possible, of the external environment (Barney, 1991; Selznick, 1957). This level of the environment impacts the firm's survival and performance directly. Moreover, the firm also has the most influence on this level of the environment, and can be at its most proactive in being able to manage its environment. Among the functional parameters that a firm has to consider at this level, both in an absolute and in a relative sense, are its sales level, sales growth rate, cash flow, return on equity, gross margin, net profits from operations, profits to sales ratio, and the ability to fund business through internal accruals (Covin \& Slevin, 1989; Hofer, 1980). Hambrick and Schectar (1983) mention that there are other organizational and managerial variables, like decision making, product quality, attitude, culture, and morale, that are critical at the firm level issues. Thus, the internal environment of an organization is multi-faceted in terms of performance parameters and organizational variables.

\section{Industry Level}

At this level, the impact of the environment on the firm is both direct if the industry is faring poorly and interactional if the firm is performing poorly at the same time. The proactive influence of the firm is more limited at this level, and the firm has to accept much of the industry structure and characteristics as given. It needs to change what it can, and adapt where it must. The work of Dess and Beard (1984) provides an excellent framework for measuring characteristics at this level. Their measures, at the industry level, include: (1) growth of sales, gross margin, employment, value added, number of establishments; (2) industry sales concentration; (3) concentration of inputs and outputs; (4) diversity of products; (5) instability in key parameters like sales, profits, and employment.

\section{Macro Level}

At this level, the firm operates at what can be described as inter-industry, or the macro environment level. This is the milieu of distal variables that influence the firm more than being influenced by the firm. Logically, the level of determinism (Hannan \& Freeman, 1977) would be at its highest at the macro level compared to the other two levels. The elements of this level of the environment are the overall performance of the economy measured by key economic indicators such as GNP growth, unemployment rate, consumption patterns, among others, and how a particular industry is performing in relation to other industries.

The macro environment is, in fact, composed of a number of dimensions that include the technological, political, international, and economic components. We, however, restrict our view of the macro environment to the economic dimension for two important reasons. One restriction is the need to maintain parsimony in 
order that the scope of the paper remains within limits, as a more complete explanation covering the forces in the macro environment would be prohibitively long. Two, and more important, is to keep our analysis more in line with other management researchers in this area who primarily focus on a select set of economic variables (Dill, 1958; Staw \& Szwajkowski, 1975). It is also important to note that economic forces in the environment are generally easier to operationalize both in theory development and in empirical research. We also believe that our restricted approach in conceptualizing the macro environment will allow for easier comparison across different studies. While acknowledging the importance of other dimensions, we focus primarily on the economic aspect for reasons of parsimony, operationalization, and comparability.

\section{Assessment of the Firm's Environment and Fit}

\section{Assessing Environment and Performance Measures}

Assessment of the environment has been described as an important process of strategic management and is posited to be the first link in the chain of perceptions and actions that permit the organization to adapt to its environment (Hambrick, 1981). Hrebiniak and Joyce (1985) consider environmental scanning to be a preliminary activity before organizations commit themselves to a particular strategy. The relationship between a firm's strategy and its focus on certain aspects of the external environment has been a subject of both conceptual enquiry (Aquilar, 1967; Hrebiniak and Joyce, 1985; and Porter, 1980) and empirical research (Hambrick, 1982; Jennings \& Lumpkins, 1992; Miller, 1989). Researchers maintain that beliefs and expectations of managers are formalized based on their definition of what phenomena (in their environment) are considered to be relevant, important, and desirable (Jennings \& Lumpkins, 1992). Subsequently, managers then develop strategies based on their perceptions on how to deal with specific situations (Goleman, 1985; Starbuck, 1983).

In a study of 56 firms from the Texas Savings and Loans (S\&L) industry, Jennings and Lumpkins (1992) found that firms tend to emphasize certain areas within the environment during the process of assessment depending on the strategic needs and postures of the firm. Specifically, they found that those S\&Ls with a differentiation strategy place more importance on "evaluation of opportunities" and "evaluation of customers' attitudes." Those S\&Ls with a cost leadership strategy place more importance on "evaluation of threats from competitors and regulators" and "tracking policies and tactics of competitors." They conclude, "Thus there appears to be a rather distinct difference in orientation with respect to environmental scanning based on generic strategy" (Jennings \& Lumpkins, 1992: 799).

Miller has also discussed the association between strategy and scanning activity by investigating the relationship between information processing and Porter's (1980) generic strategies. This relationship, which is extended by Tushman and Nadler (1978), suggests that effective organizational performance is a function 
between information processing demand and the organization's information processing capacity. Consequently, awareness of the three levels and their impact on the organization is an integral part of the demand for and capacity to process information. Underestimating the impact, importance, or the interrelationships of any of the levels would imply inadequate information that is being processed to assess the firm's overall environment. The firm's mechanisms to process information from the environment should be optimally designed such that it does not capture and overprocess trivial information, or fail to obtain and underprocess critical information. Thus, the ability to look at the total environment in the form of the three levels becomes increasingly important. Our suggestions are in line with Emery and Trist's concept of the "causal texture of the environment which include the processes through which parts of the environment become related to each other - the area of interdependencies that belongs to the environment itself" (1965: 22).

\section{Organization level}

Performance measures at the organization level provide information on how the firm is performing in an absolute sense based on a purely internal assessment. These absolute measures establish how close the firm is in achieving its internally defined goals. Among the functional parameters that a firm has to consider at this level include its sales level, sales growth rate, cash flow, return on equity, gross margin, net profits from operations, profits to sales ratio, and the ability to fund business through internal accruals (Hofer, 1980).

\section{Industry level}

Performance measures at the industry level provide information on how the industry is performing in the absolute sense, and the how the firm is performing in comparison to other firms in the same industry. The work of Dess and Beard (1984) provides an excellent framework for measuring parameters of how the industry is performing. Their measures, as mentioned earlier, include: (1) growth of sales, gross margin, employment, value added, number of establishments; (2) industry sales concentration; (3) concentration of inputs and outputs; (4) diversity of products; (5) instability in key parameters like sales, profits, employment, and population. In order to assess the firm's performance in relation to that of other firms in the same industry a number of financial criteria should be used such as sales growth rates, returns on equity, returns on assets, gross margins, and profits to sales ratios (Covin \& Slevin, 1989). These are useful relative measures which the firm can assess its performance in relation to referent other firms.

\section{Macro level}

Performance measures of the macro level provide information on how the industry is performing in a relative sense when compared to other industries. Staw and Szwajkowski (1975) have suggested a measure of the macro environ- 
ment by assessing the performance of the firm's industry, in relation to the financial performance of all firms and all industries in the FORTUNE 500 list. Four financial criteria, taken over a given period of time, have been suggested. These are: (1) mean return on equity; (2) mean return on sales; (3) percentage change in sales; and (4) percentage change in profits. These measures provide an indication of how a firm is performing in relation to all other firms, both within and outside the industry. This set of performance measures provides key information to the firm and helps it assess its overall performance position and its relationship with its environment. Thus, a firm may find itself in a declining macro environment and a growing industry environment, or vice versa.

\section{Assessing Fit}

The firm's response can be viewed as a process of realigning the organization to the environment in order to attain a desired level of competitive advantage. Research has discussed the need to achieve a fit between the firm and its external and internal environments (Jemison, 1981; Miles \& Snow, 1980). Organizational adaptation, as seen by contingency theorists (Aldrich, 1984; Lawrence \& Lorsh, 1967) or as seen by population ecologists (Hannan \& Freeman, 1977), is a function of congruence with the environment. Thus, improving the congruency between the environment and the organization is posited to lead to improved performance.

\section{Figure 2}

\section{The Environment-Performance-Response Linkage}

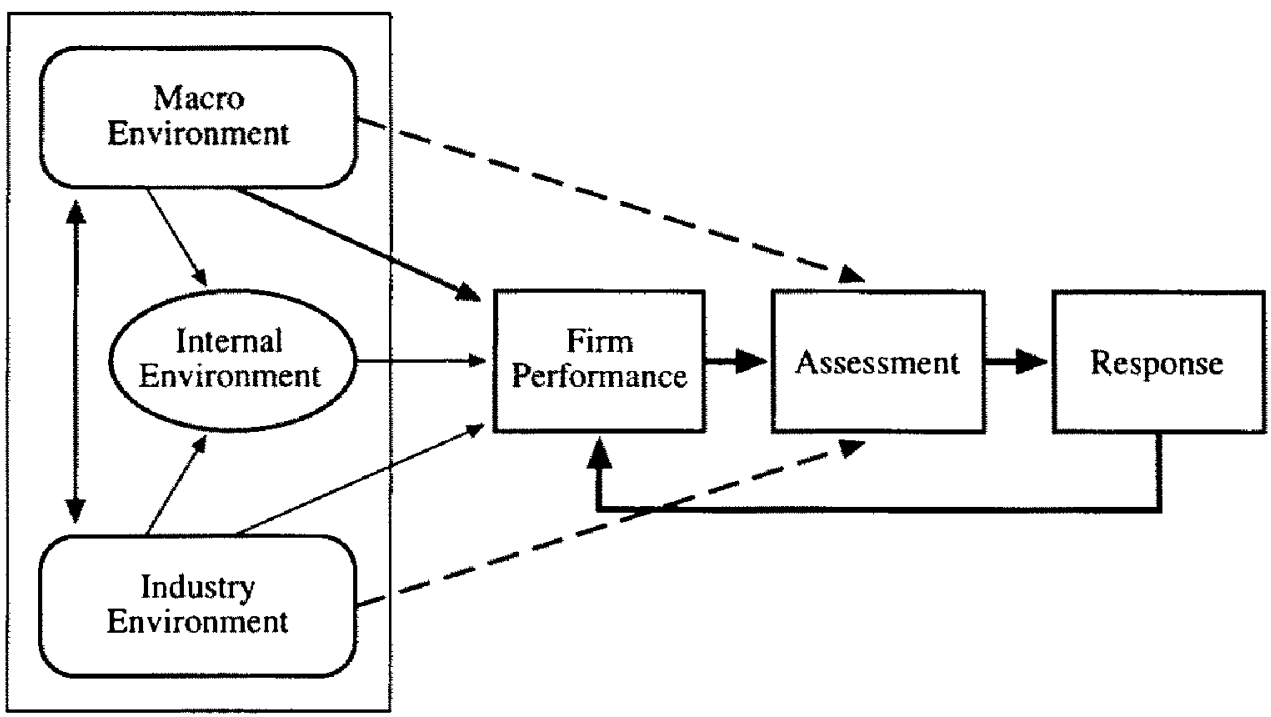

How can firms assess their environments to make sure that, given the circumstances, they have the best fit possible? This perhaps is the essence of the 
discipline of strategy - a search for a fit between an organization and its environment. The concept of fit is central in distinguishing the field of strategic management (Summer et. al, 1990) from its brethren: finance, managerial controls, human resources, marketing, and organizational behavior. Having suggested that the environment can be best understood in three levels, all of which impact the firm in direct as well as in indirect ways, the question of assessing the environment from the point of view of fit now becomes more complicated. Various fit models have been developed and tested. For example, Naman and Slevin (1993) have developed a fit model consisting of entrepreneurial style, organizational structure, and mission strategy, and empirically tested this profile against certain measures of financial performance. Venkatraman and Camillus (1984) consider the concept of fit to be fundamental to strategic management. This follows from the notion that organizational resources should be aligned to match the environmental contingencies faced by the organization (Andrews, 1971). We see the issue differently based on the multilevel model of the environment that we have suggested. Literature and research discussing strategic fit between an organization and its environment in many cases does not explicitly state what level of the environment it is addressing, consequently it is left to the reader to assume the appropriate environmental level.

Fit, therefore, is not just with the immediate environment, but it also needs to relate to the three levels mentioned earlier. An organization may be exhibiting appropriate fit for one or two levels, but not all three, and this is likely to make its performance suboptimal. We suggest that environmental assessment should encompass an appraisal of the variations in all three levels and the repercussions this has on the organization (Figure 2). There exists an interaction among the three levels of the environment which in turn determines firm's performance.

A firm's long-term viability, survival, and prosperity depends upon the overall competitive environment it operates in. Here, its task environment (Dill, 1958) at the industry level, and the forces within this level determine competition. Porter's (1980) five forces model most elegantly explains the degree of competition and rivalry a firm faces. Certainly a poor fit with the many elements of a firm's environment will heighten competition to the extent that the survival of the firm is at stake. On the other hand, the ability to optimally organize its internal resources and sub-environments will allow a firm to manage its competitive conditions better, and prevent excessive rivalry from overwhelming the firm. Some firms are able to contain and manage competition on account of its well-organized and well-deployed internal resources. Other firms are able to extend this in optimizing the forces (from suppliers, buyers, new entrants, etc.,) at the industry level. Certainly an inability to manage competition and rivalry is indicative of a poor fit at the organization or the industry level or both. It is important to conceptualize fit in terms of managing internal resources and industry level forces to not get overwhelmed by competition and rivalry. 


\section{Organizational Responses}

An important aspect of the organization-environment relationship is the ability of an organization to correctly understand and respond to the signals emanating from this interface. While the signals are difficult to measure, it is obviously important to evaluate these indicators as there is a considerable time lag between the first weak signals and the ultimate decline in measurable business performance (Lorange \& Nelson, 1987). The issues that have been raised in this paper are primarily concerned with the organization's abilities to properly assess the causes of decline, and to follow this with the most appropriate responses. With the environment operating at three levels, decline sources can be from the macro level, the industry level, or the organization level. Specific environmental levels will have different effects on organizations. We present two tables. Table 1 presents a framework where the macro environment itself is a source of decline. Other rows and columns indicate whether other levels of the environment, the industry and organization levels, are or are not sources of decline. The table also suggests that a label for each type of decline, the long- and short-term prospects for the industry and the organization, examples of industries, and finally the type of strategy the firm or organization may choose to undertake.

Table 1

Macro environment as primary source of decline and organizational responses

\begin{tabular}{|c|c|c|c|c|}
\hline \multirow{2}{*}{$\begin{array}{l}\text { Environment Level } \\
\text { Hostile Macro Level }\end{array}$} & \multicolumn{4}{|c|}{ Environmental Conditions as Causes } \\
\hline & Yes & Yes & Yes & Yes \\
\hline $\begin{array}{l}\text { Declining Industry } \\
\text { Level }\end{array}$ & Yes & Yes & No & No \\
\hline $\begin{array}{l}\text { Poorly Performing } \\
\text { Organization Level } \\
\end{array}$ & Yes & No & Yes & No \\
\hline $\begin{array}{l}\text { PROSPECTS } \\
\text { Industry ... } \\
\text { Organization } \\
\text { Short Term ... } \\
\text { Long Term ... }\end{array}$ & $\begin{array}{l}\text { Poor } \\
\text { Poor } \\
\text { Poor }\end{array}$ & $\begin{array}{l}\text { Poor } \\
\text { Good } \\
\text { Poor } \\
\end{array}$ & $\begin{array}{l}\text { Poor } \\
\text { Poor } \\
\text { Good } \\
\end{array}$ & $\begin{array}{l}\text { Poor } \\
\text { Poor } \\
\text { Good } \\
\end{array}$ \\
\hline Examples & $\begin{array}{l}\text { Railroads, } \\
\text { tobacco }\end{array}$ & $\begin{array}{c}\text { Isolated } \\
\text { businesses, } \\
\text { catering to } \\
\text { special niches } \\
\text { or tastes } \\
\end{array}$ & $\begin{array}{l}\text { Industries } \\
\text { that do well, } \\
\text { especially } \\
\text { during } \\
\text { recessions } \\
\end{array}$ & $\begin{array}{l}\text { Counter- } \\
\text { cyclical } \\
\text { industries }\end{array}$ \\
\hline Strategy Type & Collective & $\begin{array}{c}\text { Collective/ } \\
\text { Organizational }\end{array}$ & $\begin{array}{l}\text { Collective/ } \\
\text { Operational }\end{array}$ & $\begin{array}{l}\text { Collective/ } \\
\text { Operational }\end{array}$ \\
\hline
\end{tabular}


A second table is also presented. This table is structurally similar to Table 1, however, the difference is that the cause of decline is no longer from the macro environment (which have been covered in Table 1), but are either from the industry level or from the organization. What Table 2 presents is that, given the macro environment is not the source of the decline, the source of decline is from one of the two more proximal levels.

Table 2

Industry and organization levels as sources of decline and organizational responses

\begin{tabular}{|l|c|c|c|}
\hline \multicolumn{1}{|c|}{ Environment Level } & \multicolumn{3}{|c|}{ Environmental Conditions as Causes } \\
\hline Hostile Macro Level & No & No & No \\
\hline Declining Industry Level & Yes & Yes & No \\
\hline $\begin{array}{l}\text { Poorly Performing } \\
\text { Organization Level }\end{array}$ & Yes & No & Yes \\
\hline \hline $\begin{array}{l}\text { PROSPECTS } \\
\begin{array}{l}\text { Organization ... } \\
\text { Short-term... } \\
\text { Long Term... }\end{array}\end{array}$ & Poor & Poor & Poor \\
\hline $\begin{array}{l}\text { Examples } \\
\text { Poor }\end{array}$ & $\begin{array}{c}\text { Sunset industries } \\
\text { like steel, } \\
\text { extraction, black } \\
\text { and white TVs }\end{array}$ & $\begin{array}{c}\text { Individual firms } \\
\text { doing well in a } \\
\text { declining industry }\end{array}$ & $\begin{array}{c}\text { Individual firms } \\
\text { doing poorly in a } \\
\text { bountiful } \\
\text { environment }\end{array}$ \\
\hline
\end{tabular}

Typically, if the source of decline can be traced to the macro level, which in turn has negative consequences at the industry level, then firms within that industry should follow collective strategies (Astley \& Fombrun, 1983). On the other hand, if a firm is in decline due to strategic reasons at the industry level, it should develop responses that are aimed at strategic reorientation. Finally, if a firm is in decline due to internal causes related to either issues of efficiency or due to organizational reasons, it should undertake operational or tactical responses. For example, an unstable marketing environment would affect all firms in the industry while a specific firm's unstable labor union relationship could affect just the specific firm. In other words, the response pattern of the firm will have to be a combination of actions taken in correspondence to the causes of decline emanating from a multi-level environment.

\section{Collective Strategies}

One major area of the environment that may be affecting firms and causing decline is the macro level. While deterioration in the macro environment may affect the 
firm directly, it is more than likely that the firm's industry is also negatively affected. Thus an adverse macro environment is usually related to a declining industry. In this situation, firms usually have to adopt some forms of collective strategies (Astley \& Fombrun, 1983; Astley, 1984; Benson, 1975; Oliver, 1988; Dollinger, 1990; Dollinger \& Golden, 1992) in conjunction with other firms. These collective strategies can take the form of federations (Provan, 1983) or consortiums (Provan, 1984) or some other type of interorganizational cooperation.

Collective strategy has been defined as "a systematic response by a set of organizations that collaborate in order to absorb the variation present in the environment" (Astley \& Fombrun, 1983: 580). Bresser defines the objective of collective strategy to "managing mutual independence and the system dynamics of their interorganizational environment" (1988: 375). Earlier collective strategies were posited to be an option for concentrated and oligopolistic industries (Bresser, 1988; Hamel, Doz and Prahalad, 1989). The ability of a single firm in such an environment to unilaterally influence conditions for itself or the industry would be limited. Oliver (1988) exhorts the use of collective and cooperative efforts among firms as a concerted response to ubiquitous (inter-industry) environmental changes. Collective strategies would be more applicable in complex environments with the added threat of increasing dynamism. Moreover, firms lacking the ability to secure critical resources (Hambrick, 1983), access and procure information (Williamson, 1975) and coupled with the absence of slack resources to absorb this hostility, would largely benefit from collective strategies. Aldrich (1979) suggests that some firms do have the power to influence the envi. ronment on their own. In the absence of such power, collective strategies can be used as alternatives. For example, organizations facing changes in governmental agencies, social and technological subsystems, customers, and internal organizational environment would not only need operational and strategic turnaround strategies but would be required to resort to a collective response in the form of associations, lobbying, and collaboration.

We take the view that organizations, when faced with decline or possible decline, can and indeed do make strategic choices on how the effects of the environment can be handled collectively. Under such conditions, organizations form collectives like coordinating agencies, coalitions, networks, and federations. Federations, for example, are often formed when interdependent organizations find themselves engaged in activities for which they are ill-suited (Provan, 1983). Interorganizational cooperation is a major strategy used by organizations to enhance their capacity to serve clients or to acquire resources through the formation of ties with other organizations (Provan, 1984). Interorganizational formations can be internally driven, or may form due to pressures from regulatory commissions (McDaniel, 1978). Either way, our contention is that some form of collective strategy is an appropriate response for an organization if it assesses that the source of decline is from the macro environment. Under extreme conditions, when the macro environment is considered to be unsupportive, Staw and Szwajkowski (1975) have found empirical evidence of illegal collective strategies being under- 
taken such as collusion, price fixing, refusal to deal, monopoly, tying arrangements, price discrimination, foreclosure, and conspiracy.

\section{Firm Strategies}

When firms find that the cause of decline is not due to the macro environment, but is within the context of the industry it operates in, it has to assess its own strategic posture to determine whether it has an appropriate fit with its industry environment. In this situation, the suggestions made by Hofer (1980) to assess the organization's strategic position in the industry would be most useful. He suggested that the organization's current operating and strategic health be mapped so as to determine appropriate responses to improve its current position. Strategic turnaround is associated with declines which are primarily due to misalignment of the firm with the environment. The thrust of strategic turnaround is one of innovation, application of new ideas, and doing new things, while operational turnaround dictates maintaining the variety of the current strategy with more efficiency (Hofer, 1980). In other words, strategic turnarounds can be associated with doing the right things, while operational turnarounds can be associated with doing the things right. A strategic turnaround would mean that the focus of the organization needs to be shifted from one area of competency to another. Strategies at this level include divestiture, repositioning, and handling of exit barriers (Harrigan, 1985). Other strategic options are usually at a corporate level and include those of diversification, joint ventures, mergers, acquisitions, and vertical integration.

The industry environment is concerned with ends, and the objectives of a firm are a part of this level of the environment. Astley and Fombrun (1983) have - suggested that corporate and business strategies are appropriate for this level of the environment. It is usually at this level that matters pertaining to what is called corporate strategy are followed. Strategic choice operates at three levels (Dill, 1957). One is the choice of industry, the second is choice of market, and the third is choice of product and price. Thus, key decisions of reconsidering ends is a part of corporate strategy which generally covers decisions of whether to enter or exit a particular industry. Furthermore, strategic issues at the industry environment are also matters of business strategies, which are primarily concerned with means to achieve particular ends. Decisions of this kind have less to do with whether or not to enter an industry, but are issues of what best to do within the industry in order to overcome decline. Product diversification, pricing policies, emphasis on $R \& D$, capital investment, technological innovation, and the like are different means to achieve given ends.

\section{Operational Responses}

Another level that a firm may recognize as the fundamental source of decline may be at the organization level itself. Under these circumstances, the firm has to 
undertake operational and tactical actions like better management of plant and equipment and related efficiency-oriented activities. Such a concerted response by the organization to decline due to temporary or cyclical industry contractions based on efficiency-related postures is termed as operational turnaround (Hofer, 1980). Actions that include pricing, plant and equipment, marketing, receivables, inventories, capacity utilization, productivity, quality, and material management should really be considered operational issues. (Hambrick \& Schectar, 1983; Hofer, 1980).

Operational responses include intra-organizational and managerial variables (Hambrick \& Schectar, 1983) like structure, decision-making processes, delegation, centralization, and other similar variables. Lorange and Nelson (1987) have pointed out other internal causes that are responsible for firm decline like top management self-deception, hierarchy orientation, cultural rigidity, conformity, and a dysfunctional need for consensus and compromise. Responses to address decline from within the organization itself have to first recognize that the organization is the source of decline. This is a key step in making an appropriate decision that specifically confronts problems from within. Lorange and Nelson (1987) suggest a number of steps that include explicitly defining goals, subgoals, and benchmarks, identify and address key competitors and customers, link job with responsibility, and address issues of structure and processes.

\section{Discussion and Conclusions}

This paper considers firm-environment fit as an important ingredient towards achieving competitive advantage. We extend the logic to the attempted turnaround process. In other words, we look at this process as a mechanism for realigning the organization with the exigencies of the environment in order to reclaim the lost position of competitiveness. This argument indicates that there exists a great need to be more precise in studying the effects of environmental conditions on declining organizations. A lot of research looks at the environment as a univariate construct, and perhaps this is justified from the context of the research question. We have suggested a more elaborate view so that actions or responses that firms take can be understood based on the impact different levels of the environment have on the firm (see Figures 1 and 2). Given the suggested three level structure of the environment - macro, industry and organization - we propose that there are a number of different possibilities in the way the overall environment acts. Leaving out the impact, importance, or the interrelationship of any of the levels would imply either that inadequate information is being processed to assess a firm's overall environment, or redundant information is being processed.

Ferris, Schellenberg and Zammuto (1984) have suggested that environmental conditions of organizations differ, hence firm-level responses for dealing with decline should consequently be different. We recommend that the strategy and tactics the firm plans to adopt need to be consistent with the magnitude and source of change taking place in the environment. A range of environmental conditions 
are possible based on our framework (Table 1). At the one end is when the three levels of the environment are positive. Under this condition, decline is not likely to occur and is not addressed in our paper. At the other end is when the macroenvironment is in decline, indicating an economy in recession, without there being a specific negative impact on the industry or firm. Our framework addresses conditions that occur between these two extremes.

An important question arises as to the true meaning of "fit" between an organization and the different levels of its environment. Does fit automatically assure the firm of success, or is success a higher order set of activities, and perhaps "fit" is only a means to prevent failure? This is a difficult question to answer, and is a theoretical and research issue that is yet to be fully explored. An important strategic issue may have been overlooked in management research is the appropriateness of classifying strategies into two factors in terms of failure-preventors and success-providers (Varadarajan, 1985). Most strategy researchers have not seriously considered this two-factor classification when undertaking research in strategic management (McKee, Conant, Varadarajan \& Mokwa, 1992 are among the few exceptions). We take the position that alignment of a firm with its environment is more like a failure prevention strategy (Varadarajan, 1985; McKee, Conant, Varadarajan \& Mokwa, 1992) and is akin to necessary conditions. However, the process of alignment while distinct, are closely related to strategies that have to be implemented to obtain success. Strategy scholars have suggested that failurepreventor variables (the necessary conditions) are distinct from the success-provider variables (the sufficient conditions), and go on to suggest that failurepreventor skills are necessary but not sufficient for superior organizational performance. While we suggest that the process of aligning the firm with its environment is a failure-preventor (necessary condition) and subsequent strategies are success providers (sufficient conditions), enough theoretical and empirical work has not been done in any conclusive manner in this area.

We recommend the use of collective strategies to overcome decline resulting from environmental changes beyond the scope of any one individual firm, the use of firm strategies to manage firm deterioration arising out of industry-level environmental difficulties, and the use of operational strategies to readjust any deviation attributable to within-firm disturbances. (While it appears that our discussion suggests that there is a set of responses for each level of the environment causing the decline, the reality is that one, two, or all three levels of the environment can contribute to decline.) Consequently, multiple responses based on our suggestions would be appropriate. It is possible that particular internal corporate strengths of an organization would make certain strategic options more appropriate for specific organizations and their environments. Even when external environmental factors are held constant, several business strategies, depending on the internal environment, may be applicable to bring about a successful turnaround. Our intention behind this paper is to emphasize that the environment is a multilevel interrelated construct. Decline conditions can be caused by one or more of 
these levels, and these levels themselves may be moving in different directions. Finally, turnaround strategies have to be related and linked to the appropriate environment level or levels.

\section{References}

Aldrich, H. (1979). Organization and environments. Englewood Cliffs, NJ: Prentice- Hall.

Andrews, K. (1971). The concept of corporate strategy. Homewood, IL: Irwin.

Aquilar, F. J. (1967). Scanning the business environment. New York: Macmillan.

Astley, W. G., \& Fombrun, C. J. (1983). Collective strategy: social ecology of organizational environments. Academy of Management Review. 8 (4), 576-587.

Astley, W. G. (1984). An appreciation of collective strategy. Academy of Management Review. 9 (3), 526-535.

Barker, V. (1992). Corporate turnarounds as strategic reorientations: A field study of turnaround attempts from firm-based decline. Unpublished doctoral dissertation, University of Illinois at Urbana-Champaign.

Barker, V., \& Duhaime, I. (In press). Toward a thorough understanding of strategic change in turnaround companies: theory and evidence. Strategic Management Journal.

Barney, J. (1991). Firm resources and sustained competitive advantage. Journal of Management. 17 (1), 99-120.

Benson, J. K. (1975). The interorganizational network as a political economy. Administrative Science Quarterly, 20, 229-249.

Bibeault, D. (1982). Corporate turnaround. New York: McGraw-Hill.

Bourgeois, L. J. (1985). Strategic goals, perceived uncertainty, and economic performance in volatile environments. Academy of Management Journal. 28 (3), 548-573.

Beard, D. W., \& Dess, G. G. (1981). Corporate-level strategy, business-level strategy, and firm performance. Academy of Management Journal, 24, 663-688.

Bresser, R. (1988). Matching collective and competitive strategies. Strategic Management Joumal. 9, 375-385.

Cameron, K., Whetten, D., \& Kim, M. (1987). Organizational dysfunctions of decline. Academy of Management Journal. 30 (1), 126-138. 
Cameron, K., Sutton, R., \& Whetten, D. (1988). Issues in organizational decline. In K. Cameron, R. Sutton, and D. Whetten (Eds.), Readings in organizational decline: Frameworks, research and prescriptions, 3-19. Boston: Ballinger.

Castrogiovanni, G. J. (1991). Environmental munificence: a theoretical assessment. Academy of Management Review, 16 (3), 542-565.

Castrogiovanni, G. J. (1995). Business turnaround processes: reconsidering the role of retrenchment. Proceedings of the Southwest Academy of Management's 37th annual meeting, 14-18.

Child, J. (1972). Organizational structure, environment and performance: The role of strategic choice. Sociology, 6, 1-21.

Covin, J., \& Slevin, D. (1989). Strategic management of small firms in hostile and benign environments. Strategic Management Journal, 10, 75-87.

Dess, G., \& Beard, D. (1984). Dimensions of organizational task environments. Administrative Science Quarterly, 29, 52-73.

Dill, W. R. (1958). Environment as an influence of managerial autonomy. Administrative Science Ouarterly, 2 (4), 409-443.

Dess, G., Ireland, R., \& Hitt, M. (1988). Industry effects and strategic management research. Paper presented at the Academy of Management meeting, Anaheim, CA.

Dollinger, M. (1990). The evolution of collective strategies in fragmented industries. Academy of Management Review, 15 (2), 288-265.

Dollinger, M., \& Golden P. (1992). Interorganizational and collective strategies in small firms: Environmental effects and performance. Journal of Management. 18 (4), 695 715.

D'Aveni, R. (1989). The aftermath of organizational decline: a longitudinal study of the strategic and managerial characteristics of declining firms. Academy of Management Journal, 32 (3), 577- 605.

Emery, F. E., \& Trist, E. L. (1965). The causal texture of organizational environments. Human Relations, 18 (1), 21-32.

Gerloff, E. A., Muir, N. K., \& Bodensteiner, W. D. (1991). Three components of environmental uncertainty: An exploratory analysis of the effects of aggregation. Journal of Management, 17 (4), 749-768.

Goleman, D. (1985). Vital lies, simple truths: The psychology of self-deception. New York: Simon and Schuster. 
Hambrick, D. (1981). Specialization of environmental scanning activities among upper level executives. Journal of Management Studies, 18, 213-220.

Hambrick, D. (1982). Environment scanning and organization strategy. Strategic Management Journal, 3, 159-174.

Hambrick, D., \& D'Aveni, R. (1988). Large corporate failures as downward spirals. Administrative Science Quarterly, 33, 1-23.

Hambrick, D., \& Schectar, S. (1983). Turnaround strategies for mature industrial-product business units. Academy of Management Journal, 26 (2), 231-248.

Hambrick, D. (1985). Turnaround strategies. In Handbook of Business Strategy, 10.110.32. Boston: Warren, Gorham, and Lamont.

Hannan, M., \& Freeman, J. (1977). The population ecology of organizations. American Journal of Sociology. 78 (2), 929-964.

Hannan, M., \& Freeman, J. (1984). Structural Inertia and Organizational Change. American Sociological Review, 49, 149-164.

Harrigan, K. (1980). Strategies for declining businesses. Lexington, MA: Lexington Books, 1980.

Harrigan, K. (1985). Strategic flexibility: A management guide for changing times. Lexington, MA: Lexington Books.

Hrebiniak, L., \& Joyce, W. (1985). Organizational Adaptation: Strategic Choice and Environmental Determinism. Administrative Science Quarterly, 30, 336-349.

Hofer, C. (1980). Turnaround strategies. Joumal of Business Strategy. 1, 19-31.

Jemison, D. (1981). The importance of an integrated approach to strategic management. Academy of Management Review, 6, 601-608.

Jennings D., \& Lumpkin, P. (1992). Insights between environmental scanning activities and porter's generic strategies: An empirical analysis. Journal of Management, 18 (4), 791-803.

Levine C. H. (1978). Organizational decline and cutback management. Public Administration Review. 38, 316-325.

Lorange, P., \& Nelson, R. T. (1987). How to recognize - and avoid - organizational decline. Sloan Management Review, Spring, 41-48.

McDaniel, J. P. (1978). Maryland Health Care System, Inc.: A creative response to change." Health Care Management Review, 3 (4), 29-50. 
McKee, D. O., Conant, J. S., Varadarajan, P. R., \& Mokwa, M. P. (1992). Success-producer and failure-preventor marketing skills: A social learning theory interpretation. Journal of the Academy of Marketing Science, 20 (1), 17-26.

Miles R., \& Snow C. (1978). Organizational strategy, structure and processes. New York: McGraw Hill.

Miller, D. (1989). Matching strategies and strategy making: Process, content, and performance. Human Relations, 42, 241-260.

Naman, J. L., \& Slevin, D. P. (1993). Entrepreneurship and the Concept of fit: A model and empirical tests. Strategy Management Joumal, 14, 137-153.

Oliver, C. (1988). The collective strategy framework: An application to competing prediction of isomorphism." Administrative Sciençe Quarterly, 33, 543-561.

Pearce, J., \& Robbins, D. (1994). Retrenchment remains the foundation of business turnaround. Strategic Management Journal, 15 (5), 407-417.

Pearce J., \& Robbins, D. K. (1993). Toward improved theory and research on business turnaround. Journal of Management. 19, 613-636.

Porter, M. E. (1990). Competitive strategy. New York: Free Press.

Provan, K. G. (1983). The federation as an interorganizational linkage. Academy of Management Review, 8 (1), 79-89.

Provan, K. G. (1984). Interorganizational Cooperation and Decision Making Autonomy in a Consortium Multihospital System. Academy of Management Review.9 (3), 494504.

Robbins, D. K., \& Pearce, J. (1992). Turnaround: Retrenchment and recovery. Strategic Management Joumal, 13 (4), 287-309.

Selznick, P. (1957). Leadership in administration, New York: Harper and Row.

Sharfman, M. P., \& Dean, J. W. (1991). Conceptualizing and measuring the organizational environment: A multidimensional approach. Journal of Management. 17 (4), 681-700.

Starbuck, W. H. (1976). Organizations and their environments. In M.D. Dunnette's (ed.), Handbook of industrial and organizational psychology, 1069-1123. Chicago: Rand McNally College Publishing Co.

Starbuck, W. H. (1983). Organizations as action generators. American Sociological Review, 43, 91- 102 . 
Starbuck, W., Greve, A., \& Hedburg, B. (1978). Responding to crisis. Journal of Business Administration. 9, 111-137.

Staw, B. M., \& Szwajkowski, E. (1975). The scarcity-munificence component of organizational environments and the commission of illegal acts. Administrative Science Quarterly,20, 345-354.

Stopford J. M., \& Baden-fuller C. (1990). Corporate rejuvenation. Journal of Management Studies. 27, 399-415.

Thomas, P. (1980). Environmental scanning - the state of the art. Long Range Planning. 13, 20-28.

Tushman, M. L., \& Nadler, D. A. (1978), Information processing as an integrating concept in organization design. Academy of Management Review, 3, 613-624.

Varadarajan, P. R. (1985). The two-factor classification of competitive strategy variables. Strategic Management Journal. 6, 357-375.

Venkatraman, N., \& Camillus, J. (1988). Exploring the Concept of "Fit" in Strategic Management. Academy of Management Review, 9 (3), 513-525.

Whetten, D. (1987). Organizational growth and decline processes. Annual Review of Sociology, 13, 335-358.

Williamson, O. E. (1975). Markets and Hierarchies: Analysis and Anti-trust Implications. New York: Free Press.

Ananda Mukherji is working as an Assistant Professor at Texas A\&M International University in Laredo, Texas. He received his Ph.D. from The University of Memphis and his Masters from the Xavier Labour Relations Institute in India. He worked as a systems and management consultant for a number of years, and ran his own business subsequently. His research interests include competitive strategies, inter-firm relations, international business strategy, and agency issues.

Ashay Desai is currently working as an Assistant Professor at the University of Wisconsin - Oshkosh. He received his Ph.D. from The University of Memphis, and his MBA from The University Of Wyoming. He previously worked for the Indian Hotels Company in the Human Resources Department. Dr. Desai's research interests have focused on decline and turnaround, issues of international competitiveness, strategic planning and corporate governance.

John Francis is as an Instructor at Mississippi College in Jackson. He received his MBA from Samford University and is completing his Ph.D. degree in Strategic Management at The University of Memphis. He has worked for a few years with an engineering firm in the construction industry. His research interests include strategic and international management, with particular emphasis on institutional theory and born global firms. 